Personalidade Acadêmica Homenageada:

Raymundo Juliano Feitosa (Universidade Federal do Rio Grande do Norte - UFRN)

\title{
O FUTURO SERÁ COMO O PASSADO: O TERRORISMO SÍRIO COMO JUSTIFICATIVA PARA A MIXOFOBIA ALEMÃ
}

\section{THE FUTURE WILL BE LIKE THE PAST: SYRIAN TERRORISM AS JUSTIFICATION FOR GERMAN MYXOPHOBIA}

\section{THAÍS PEIXOTO SARAIVA COIMBRA}

Graduanda em Direito, modalidade integral, pela Escola Superior Dom Helder Câmara. BELO HORIZONTE - MG. E-mail: thaisppsar26@gmail.com

\section{CAIO AUGUSTO SOUZA LARA}

Mestre e Doutor em Direito pela Faculdade de Direito da Universidade Federal de Minas Gerais - UFMG. Professor da Escola Superior Dom Helder Câmara. Pesquisador associado ao Programa RECAJ-UFMG - Acesso à Justiça e Solução de Conflitos. Secretário de Comunicação do Conselho Nacional de Pesquisa e Pósgraduação em Direito - CONPEDI. Belo Horizonte-MG. E-mail: caiolarabh@yahoo.com.br.

\section{RESUMO}

Acontece nos tempos hodiernos um enorme salto no contingente de refugiados que batem à porta da Europa em busca de asilo, entretanto muros são apressadamente erguidos para evitá-los. Sendo assim, é necessário compreender que o mundo vive uma crise humanitária e reconhecer a nossa interdependência como espécie é o primeiro passo para parar de segregar cotidianamente os indivíduos no âmbito social. A Guerra civil ocorrente na Síria desde 2011, iniciada dentro do contexto da Primavera Árabe, causou uma enorme onda de imigrações para os países 


\section{Personalidade Acadêmica Homenageada:}

Raymundo Juliano Feitosa (Universidade Federal do Rio Grande do Norte - UFRN)

europeus, dentre eles a Alemanha sendo um dos principais focos, tendo recebido em 2015 cerca de 98.783 solicitações para refúgio de Sírios. Entretanto, os cidadãos não são tão receptivos devido a mixofobia existente, construída desde a Segunda Guerra mundial contra os não arianos e reforçada na questão dos Sírios, implicitamente, com a possível "ameaça", suposta pelos cidadãos, do terrorismo existente na Guerra Síria ser transferido ao país Alemão receptor de refugiados. O problema objeto da investigação científica proposta é: o terrorismo ocorrente na Síria serve como justificativa da mixofobia (disfarçada) alemã para a comunidade internacional? A partir das reflexões preliminares sobre o tema, é possível afirmar inicialmente que a mixofobia é algo que sempre existiu mundialmente, entretanto é encoberto pelas convenções sociais que visam um bem-comum, um tratamento igualitário das pessoas independente de sua etnia. Sendo assim, é necessário uma "justificativa" para a repulsão dos Alemães contra os imigrantes Sírios, que provavelmente se baseará na Soberania Nacional e como tais imigrantes tornam o país Alemão pior para se viver, menos seguro para seus cidadãos nativos, pautando assim no terrorismo, ocorrente na Guerra Síria, seus argumentos para inferiorização desses imigrantes. Diante disso, o objetivo geral do trabalho é analisar a situação dos imigrantes Sírios na Alemanha de modo a constatar a presença da mixofobia desenvolvida desde a Segunda Guerra mundial até os dias atuais contra tais estrangeiros, verificando a utilização do Terrorismo, presente na Guerra Síria, como justificativa para reprovar a presença desses imigrantes no país Alemão. Sendo assim, essa pesquisa pertence à vertente metodológica jurídico-sociológica e no tocante ao tipo de investigação, foi escolhido, na classificação de Witker (1985) e Gustin (2010), o tipo jurídico-projetivo. O raciocínio desenvolvido na pesquisa será predominantemente dialético. De acordo com a técnica de análise de conteúdo, afirma-se que se trata de uma pesquisa teórica, o que é possível a partir da análise de conteúdo dos textos doutrinários, normas e demais dados colhidos na pesquisa. Em suma, a conclusão parcial diante do estudado até então, é que seguindo a hipótese, no caso da Alemanha, existe desde a Segunda Guerra mundial um preconceito por parte da população contra os estrangeiros, principalmente os não "arianos", algo que foi alimentado através das décadas de 
Personalidade Acadêmica Homenageada:

Raymundo Juliano Feitosa (Universidade Federal do Rio Grande do Norte - UFRN)

maneira implícita após o total fracasso histórico da tentativa de supremacia de uma etnia sobre outra. Entretanto, isso não é algo exclusivo do povo Alemão e sim do próprio ser humano que possui aversão ao estranho, de acordo com Bauman, manifestado nas relações interpessoais através da história. Destarte, o terrorismo que o país Sírio é acometido, é enxergado com pavor pelos países receptores de imigrantes, como a Alemanha, pois citando o estudo de Leite Filho (2003, p.19) publicado na Revista Jurídica,"o uso da força por qualquer Estado, no sistema internacional, seja mediante uma guerra declarada ou intervenções militares com objetivos humanitários, sempre significa sofrimento, violência, morte, danos materiais e psicológicos, medo e muito desprezo pelo Direito Internacional”. Logo, a mixofobia é velada pelo medo dos povos serem prejudicados e deve ser combatida imediatamente, afinal antes de sermos povos de diferentes etnias, pertencemos a uma só raça, a humana.

PALAVRAS-CHAVE: Mixofobia; Direito Internacional; terrorismo; Síria; Alemanha.

\section{REFERÊNCIAS}

BAUMAN, Zygmunt. Estranhos à nossa porta. 1‥ ed. Rio de Janeiro: Zahar, 2017.

BAUMAN, Zygmunt. Vidas desperdiçadas. Rio de Janeiro: Jorge Zahar, 2005.

BENNHOLD, Katrin. Empatia e preconceito aguardam refugiados Sírios na Alemanha. The New York Times. Disponível em: https://www1.folha.uol.com.br/mundo/2015/09/168286

4-empatia-e-preconceito-aguardam-refugiados-sirios-na-alemanha.shtml Acesso em: $13 / 05 / 2019$

CAVALCANTI, Klester. Dias de inferno na Síria. 1a‥ed. São Paulo: Benvira, 2012.

LEITE FILHO, Jaime de Carvalho. Dimensões internacionais para o Terrorismo de Estado. Revista Jurídica - UNICURITIBA. no 03 (2003). Disponível em: http://revista.unicuritiba.edu.br/index.php/RIMA/article/view/226/198. Acesso em: 23 maio 2019. 
Personalidade Acadêmica Homenageada:

Raymundo Juliano Feitosa (Universidade Federal do Rio Grande do Norte - UFRN)

GUSTIN, Miracy Barbosa de Sousa; DIAS, Maria Tereza Fonseca. (Re)pensando a pesquisa jurídica: teoria e prática. $3^{a}$. ed. Belo Horizonte: Del Rey, 2010.

MISAILIDIS, Mirta G. Lerena. MOURA, Sthéphanie Winck Ribeiro de. A política imigratória seletiva e a tutela jurídica dos trabalhadores imigrantes no Brasil. Revista Jurídica - UNICURITIBA. v. 2, n. 39 (2015). Disponvível em: http://revista.unicuritiba.edu.br/index.php/RevJur/article/view/1544/1058. Acesso em 26 maio 2019.

POR QUE OS REFUGIADOS querem ir para a Alemanha? Portal BBC - 08 set. 2015. Disponível em: https://www.bbc.com/portuguese/noticias/2015/09/150908_europa_refugiados_hb. Acesso em: 13 de Maio de 2019.

ROCHA, Camila; SÁ, Klarissa Lazzarin. As políticas migratórias excludentes da união europeia como fator de produção do Homo Sacer. Santa Cruz do Sul, UNISC. Tese nível Doutorado, II mostra nacional de trabalhos científicos, Universidade de Santa Cruz do Sul, Santa Cruz do Sul, 2016.

WERMUTH, Maiquel Ângelo Dezordi. A produção da vida nua no patamar de (in)distinção entre direito e violência. São Leopoldo, UNISINOS. Tese nível Doutorado, Programa de Pós-Graduação em Direito, Unidade acadêmica de Pesquisa e Inovação, Universidade do Vale do Rio dos Sinos, São Leopoldo, 2014.

WITKER, Jorge. Como elaborar una tesis en derecho: pautas metodológicas y técnicas para el estudiante o investigador del derecho. Madrid: Civitas, 1985. 